\title{
VILLARROEL, RAÚL
}

\section{Interesarse por la vida. Ensayos bioéticos y biopoliticos \\ Santiago de Chile, Editorial Universitaria, 2014, 224 pp.}

Los ensayos reunidos en este libro se proponen examinar, con la mirada dialogante y crítica del filósofo, algunos de los más complejos escenarios en los que hoy se exhibe la condición del ser vivo y de la vida. La obra nos invita a transitar por las complejas implicancias bioéticas y biopolíticas que constituyen el horizonte conceptual de este conjunto de problemas. Es en este contexto reflexivo en el que el autor estima que debieran enmarcarse las múltiples discusiones contemporáneas referidas a la vida y el ambiente natural.

Teniendo a la vista los riesgos reales y potenciales que se ciernen sobre el futuro de nuestra existencia y la de futuras generaciones, debemos meditar acerca del curso que queremos imprimir al desarrollo de la investigación científica y de las implementaciones tecnológicas con que buscamos avanzar en la solución de los problemas del presente y el porvenir. Raúl Villarroel señala que se requiere una reflexión crítica sobre los fines y medios que definen al avance del conocimiento, y acerca de los cambios sociales, económicos, políticos y culturales que la ciencia hace posible. A su juicio, el proceso de producción del conocimiento no puede ser cabalmente entendido si no se le vincula con el papel que cumple en la estructuración del poder en la sociedad capitalista y en el contexto de la economía de mercado.

Lejos de constituir una posición oscurantista y tecnofóbica, "interesarse por la vida" no significa sino poner atención al deber de precaución que se impone a la hora de ordenar y dirigir hacia el mejor destino la actividad científica y la diseminación y transferencia social de sus logros.

Ya que todo parece indicar que ha llegado la hora de reconsiderar el voluntarioso impulso que ha movido a la ciencia en todas sus dimensiones, que no reconoce límites en su desarrollo y avanza irrestrictamente en procura de hacer todo lo que resulte posible hacer, este libro invita a poner en sintonía todas las voces del presente para abrir un diálogo amplio y productivo, en el que converjan múltiples miradas y sensibilidades alternativas a la del mero imperativo económico y político que la dirige actualmente. De este modo — cree su autor-, podríamos fortalecer la responsabilidad ética que el mañana reclama y precavernos de las amenazas que acechan tras el progreso material de nuestro tiempo, en que - según se entiende- se ha hecho entrar a la vida y sus mecanismos en los dominios de los cálculos explícitos, distribuyéndose lo viviente en registros de valor y de utilidad, viéndose lo biológico enteramente reflejado en lo político y el individuo humano capturado en la grilla del poder extendido a partir del saber.

Álvaro Quezada Sepúlveda 